\title{
Jewish Law and the Concept of Negligence
}

Steven F. Friedell

Rutgers Law School

Follow this and additional works at: https://digitalcommons.tourolaw.edu/lawreview

Part of the Civil Law Commons, and the Torts Commons

\section{Recommended Citation}

Friedell, Steven F. (2021) "Jewish Law and the Concept of Negligence," Touro Law Review. Vol. 36: No. 4, Article 6.

Available at: https://digitalcommons.tourolaw.edu/lawreview/vol36/iss4/6

This Symposium: Jewish Law in Comparative Context is brought to you for free and open access by Digital Commons @ Touro Law Center. It has been accepted for inclusion in Touro Law Review by an authorized editor of Digital Commons @ Touro Law Center. For more information, please contact Iross@tourolaw.edu. 


\title{
JEWISH LAW AND THE CONCEPT OF NEGLIGENCE
}

\author{
Steven F. Friedell ${ }^{*}$
}

For over a century, scholars have maintained that Jewish tort law includes a doctrine of negligence. ${ }^{1}$ Some have suggested that only part of this law is based on negligence and that other parts are based on strict liability. ${ }^{2}$ Others argue that all Jewish tort law is founded on the concept of negligence. ${ }^{3}$ Some make the case that parts of Jewish law resemble Learned Hand's formula. ${ }^{4}$

If by "negligence" we mean breach of a legal duty to take care, 5 then Jewish law indeed embodies the concept. ${ }^{6}$ That definition, however, tells us nothing about the type of care that must be taken. Probably most lawyers define "negligence" to mean either a failure to exercise reasonable care in the circumstances ${ }^{7}$ or a finding, based on the risk created, that the expected harm of the defendant's conduct

\footnotetext{
* Professor, Rutgers Law School. My thanks to Michael Lewyn and Bernard Jackson for their helpful comments on an earlier draft.

${ }^{1}$ Louis N. Dembitz, 1 Jewish Encyclopedia 159 (1901). In some of my earlier writing I have asserted that Jewish law includes the negligence concept. See Steven F. Friedell, Some Observations on the Talmudic Law of Torts, 15 RUTGERS L.J. 897, 903 (1984).

${ }^{2}$ Asher Gulak, Yesodei Ha-Mishpat Ha-Ivri 31-32 (1922); B.B. Lieberman, Torts in Jewish Law, 9 J. COMP. Legis. \& INT'L L. 231-32 (1927); I.S. ZuRI, TORT OF NEGLIGENCE 11 (1937) (in Hebrew).

${ }^{3}$ SHALOM AlbeCK, 20 ENCYClOPAEdia JUdAica 63-64 (2d ed. 2007).

${ }^{4}$ Yuval Sinai \& Benjamin Shmueli, Maimonides and Contemporary Tort THEORY 264-65, 282-83 (2020) (discussing injury caused by "tooth and foot"); Yuval Sinai \& Benjamin Shmueli, Calabresi's and Maimonides's Tort Law TheoriesA Comparative Analysis and a Preliminary Sketch of a Modern Model of Differential Pluralistic Tort Liability Based on the Two Theories, 26 YALE J.L. \& HuMAn. 59, 92, 125-26 (2014) (hereinafter Sinai \& Shmueli, Preliminary Sketch).

${ }^{5}$ Lieberman, supra note 2, at 231; JOHN SALMOND, THE LAW OF TORTS 21 (5th ed. 1920).

${ }^{6}$ Mishnah, Bava Kamma 1:1.

${ }^{7}$ E.g., Saldana v. Williams, No. 07-19-00001-CV, 2020 WL 1880954, at *2-3 (Tex. Ct. App. Apr. 15, 2020); City of Andover v. Southwestern Bell Tel., L.P., 153 P.3d 561, 565 (Kan. Ct. App. 2007).
} 
outweighs the utility of the defendant's actions. ${ }^{8}$ This article will argue that negligence in these senses is almost completely foreign to the classical sources of Jewish law. Although Maimonides employs a cost/benefit analysis to explain one of the rules of liability, ${ }^{9}$ it is not a dominant feature of rabbinic tort law. Instead, that law provides a set of particular rules of liability, not a standard of conduct. Nonetheless, in recent years, rabbis have begun to incorporate the concept of negligence into Jewish law. Surprisingly, this has occurred in the area of medical malpractice, an area where, according to the Shulhan Arukh, doctors have been liable only in a Heavenly court for their errors. ${ }^{10}$

Jewish tort law often provides less compensation than is required by American law, but it also demands religious obligations unknown to American law. Under American law, a plaintiff suffering personal injury is entitled to recover compensation for past and future lost wages, pain and suffering, and medical expense. ${ }^{11}$ In cases of malicious or wanton misconduct, most states allow recovery for punitive damages. ${ }^{12}$ By contrast, under Jewish law, liability for personal injuries caused by one's animals, property, or hazardous conditions that one has created are usually limited to nezek ${ }^{13}$ a measure of the present value of a victim's lost future wages calculated by assuming the victim was for sale in the slave market. ${ }^{14}$ When a person injures another by

\footnotetext{
${ }^{8}$ See Restatement (Third) OF TORTS $\S 3$ (AM. LAW Inst. 2010) (establishing the primary factors that determine whether conduct is negligent are the foreseeability of harm, the foreseeable severity of the harm, and the burden of needed precautions); RESTATEMENT (SECOND) OF TORTS $\S 283 \mathrm{cmt}$. e (AM. LAW INST. 1965) (providing that the determination of whether the risk is unreasonable depends on "whether the magnitude of the risk outweighs the value which the law attaches to the conduct which involves it"); RESTATEMENT (FIRST) OF TORTS $§ 291 \mathrm{cmt}$. b (AM. LAW INST. 1934) ("Conduct is not negligent unless the magnitude of the risk involved therein so outweighs its utility as to make the risk unreasonable."). But see Richard W. Wright, Hand, Posner and the Myth of the Hand Formula, 4 THEORETICAL INQ. L. 145 (2003) (arguing that the Hand formula has not influenced court decisions).

${ }^{9}$ See infra notes 55-57.

${ }^{10}$ See infra note 73.

11 Dan B. Dobbs, Paul T. Hayden \& Ellen M. Bublick, Torts and COMPENSATION 883 (8th ed. 2017).

${ }^{12} I d$.

${ }^{13}$ If a person sets a fire, the recoverable damages are the same as if the damage was done by the defendant's body. Shulhan Arukh, Hoshen Mishpat 405:1; Mishneh Torah, Hilkhot Nizkei Mammon 14:15. However, if the fire went further than expected, the defendant is liable only for nezek. Shulhan Arukh, Hoshen Mishpat 418:17.

${ }^{14}$ See Shulhan Arukh, Hoshen Mishpat 420:15.
} 
his body, damages will be at least those for nezek. ${ }^{15}$ If the defendant injures another either intentionally or with inadvertence close to intention, then Jewish law imposes liability also for pain, loss of time, and medical expense. ${ }^{16}$ For example, a person falling from a roof in a normal wind, a wind that might be expected to occur, ${ }^{17}$ is deemed to be acting with inadvertence close to intention and is liable for these extra damages. ${ }^{18}$ A person is liable also for humiliation if he acts with intent to injure, even if there was no intent to humiliate. ${ }^{19}$ A special feature of Jewish law is that it imposes a religious obligation not to injure others. ${ }^{20}$ A person who directly inflicts personal injury on another cannot atone for his wrong merely by paying damages. He must also seek forgiveness from the victim. ${ }^{21}$

Jewish tort law does not impose a single standard of care. There are different rules for injuries caused by a person's body and injuries caused by things one owns or conditions one creates. Maimonides separates these in his Code, treating the former in Hilkhot Hovel u-Mazik and the latter in Hilkhot Nizkei Mammon. A person causing injury by his body is liable whether by intention or even by $o^{\prime}$ ness. ${ }^{22}$ Examples of $o$ 'ness are falling from a roof in an unusual wind $^{23}$ or injuring another when a stone, of which one was never aware, falls out of one's lap. ${ }^{24}$ If a person acts with inadvertence such as by throwing an object further than intended, the Talmud considers this a case of shogeg. ${ }^{25}$ In case of personal injury caused by a person's

${ }^{15}$ See Shulhan Arukh, Hoshen Mishpat 421:3.

${ }^{16}$ See Rashi, Bava Kamma 27a (s.v. Chayyav b'arba'ah devarim); Shulhan Arukh, Hoshen Mishpat 421:11.

${ }^{17}$ See Rashi, Bava Kamma 56a (s.v. b'ruach she'eina metzuya).

${ }^{18}$ Rashi, Bava Kamma 27a (s.v. Ve-nitkah).

${ }^{19}$ Babylonian Talmud, Bava Kamma 27a.

${ }^{20}$ Tur, Hoshen Mishpat 389.

${ }^{21}$ Shulhan Arukh, Hoshen Mishpat 422.

${ }^{22}$ Shulhan Arukh, Hoshen Mishpat 421:3.

${ }^{23}$ Babylonian Talmud, Bava Kamma 27a.

${ }^{24}$ Babylonian Talmud, Bava Kamma 26b. The Meiri suggested that someone had put the stone in the defendant's lap while he slept. Meiri, Beit ha-Bechira, Bava Kamma 26b. It is more likely that the setting is a man who lets a small stone fall into his lap while sifting grain. Mishnah, Beitzah 1:8 (suggesting that people often select beans into one's lap using a sieve); Babylonian Talmud, Beitzah 13b (discussing a person winnowing grain who lays some on his lap); Babylonian Talmud, Sotah 14b (mentioning what happens if a pebble is found in a meal offering); Babylonian Talmud, Bava Batra 93b-94a (showing that when wheat is sold it is expected to have a certain number of pebbles).

${ }^{25}$ Babylonian Talmud, Bava Kamma $26 \mathrm{~b}$. 
body due to o'ness and shogeg, the injured plaintiff may recover only nezek. ${ }^{26}$ By contrast, if a person leaves an object on a roof and that object is blown over by an unusual wind causing injury to a person below, the defendant is not liable. ${ }^{27}$

It should be seen that the doctrine of negligence is not the basis for the above rules. Take the case of a man who goes up to a flat roof carrying a bundle with him. He puts the bundle down and lies on the roof. An unusual wind blows him and the bundle over the side. He strikes a person, and the bundle strikes someone else. Applying the rules of Jewish law described above, the man is liable for the nezek his body caused, ${ }^{28}$ but he has no liability for the injury done by his bundle. ${ }^{29}$ If Jewish law imposed liability based on negligence, either based on the lack of ordinary care or a balancing of risks and utilities, we would expect both injuries to be treated the same.

In collision cases, Jewish law imposes a set of liability rules but not a standard of conduct such as a duty to use reasonable care in the circumstances. In Jewish law, if two people walking on a public way collide when headed in different directions, one carrying a beam and one carrying a pitcher, they are both exempt because they each have permission to walk on the public way. ${ }^{30}$ Jewish law does not inquire if they used reasonable care - there is instead a fixed rule of liability. ${ }^{31}$ Similarly, if the pitcher carrier was in front of the beam carrier, the latter would be liable for breaking the pitcher unless the pitcher carrier stopped without giving warning or stopped to adjust the load. ${ }^{32}$ To take another example, under Jewish law, if a person riding a horse collides with another horse in front of him on the public way, the defendant is liable. ${ }^{33}$ The Rosh explained that a defendant mounted on a running horse must be able to stop "whenever he wants." ${ }^{\text {"34 }}$ The

${ }^{26}$ See Shulhan Arukh, Hoshen Mishpat 421:10.

${ }^{27}$ Mishneh Torah, Hilkhot Nizkei Mammon 14:16.

${ }^{28}$ Babylonian Talmud, Bava Kamma 27a.

${ }^{29}$ See Hilkhot Nizkei Mammon, supra note 27.

${ }^{30}$ Mishnah, Bava Kamma 3:5; Shulhan Arukh, Hoshen Mishpat 379:1.

${ }^{31}$ Contra CivA 005027/04 (MC Jer) Estate of Kanim v. Mivnei Rav Co., Nevo Legal Database (by subscription, in Hebrew) (March 8, 2006) (Isr.) (finding that there was no evidence of lack of reasonable care when a worker coming out of an elevator bumped into an elderly resident of a nursing home who was coming out of an adjoining elevator causing her to fall).

${ }^{32}$ Shulhan Arukh, Hoshen Mishpat 379:3.

${ }^{33}$ Shulhan Arukh, Hoshen Mishpat 378:9.

${ }^{34}$ Responsa Rosh 101:5; see CivA (MC TA) 39890/06 Yosi v. Shirbit Ins. Co., Nevo Legal Database (by subscription, in Hebrew) (Apr. 27, 2009) (Isr.) (quoting an 
modern law of negligence is different. The mere happening of an accident is not evidence of negligence, ${ }^{35}$ and an automobile driver is not liable solely because he hit another on the road. ${ }^{36}$ Instead, a fact finder must determine whether reasonable care was used in each instance.

The Jewish rules governing collision resemble some of the rules of conduct that American courts once imposed. For example, the United States Supreme Court once held that a driver who did not stop, look, and listen before crossing a railroad track was contributorily negligent as a matter of law. ${ }^{37}$ One state supreme court held that drivers at night must be able to stop their vehicles within the range of their lights. ${ }^{38}$ These courts eventually replaced these rules with the requirement that parties must act reasonably under the circumstances. ${ }^{39}$

Perhaps some might advocate a fallback position. They might argue that in Jewish law, a person is generally liable for negligence, but in the case of injury caused by one's body, including colliding while riding a horse ${ }^{40}$ liability is strict—either because of a scriptural decree $^{41}$ or because people ought to be more careful about what happens with their bodies. However, many rules of Jewish tort law are based solely on the likelihood of injury and not on notions of reasonable care or a weighing of costs and benefits. For example, if one confines sheep to a pen and locks the gate properly so that it is able to withstand a normal wind, ${ }^{42}$ he is not liable if the sheep escape and cause damage. ${ }^{43}$ The Talmudic distinction between normal and unusual winds looks only at the chance of injury. It does not take into account either the magnitude of that injury or the cost of prevention.

opinion of the Center for Practical Application written by Rabbi Yosi Sharabi and Dr. Yuval Sinai, in which the court distinguished the Rosh's opinion from the case before it where one horse kicked another horse's leg while they were riding together, and the horse that kicked did so on its own).

${ }^{35}$ See, e.g., Gift v. Palmer, 141 A.2d 408, 409 (1958); see also CivA 437/87 Cohen

v. Israel Electric Co. 44(1) PD 807, 809 (1990) (Isr.).

${ }^{36}$ Gift, 141 A.2d at 409.

${ }^{37}$ Balt. \& O. R. Co. v. Goodman, 275 U.S. 66, 69 (1927).

${ }^{38}$ Marshall v. S. Ry., 62 S.E.2d 489, 91-92 (N.C. 1950).

${ }^{39}$ Pokora v. Wabash Ry., 292 U.S. 98, 102 (1934) (dealing with railway crossings); Chaffin v. Brame, 64 S.E.2d 276, 279 (N.C. 1951) (concerning stopping a vehicle at night).

${ }^{40}$ See Responsa Rosh 101:5 (ruling that this was a case of injury by one's body).

${ }^{41}$ Shlomo Yosef Zevin, Ha-yesod ha-chiuvi shel nezikin, 4 TORAH SHE-B'AL PEH 9 (Y.L. Hacohen Maimon ed.) (1962).

${ }^{42}$ Bava Kamma 55b.

${ }^{43}$ Mishnah, Bava Kamma 6:1. 
If an ox known to gore escapes a pen due to an unusual wind, the owner is exempt. ${ }^{44}$ It does not matter how dangerous the ox is nor how severe the expected injury is likely to be.

A comparison with American law is instructive. Imagine a heavy object near the edge of a roof that would only fall over if there were an unusual wind. The object would cause great damage if it fell, and let us assume that the cost of prevention is low. The one who placed the object there might be negligent under American law but would not be liable under Jewish law because the object would not be blown over in a normal wind. Similarly, imagine a case where the defendant placed a light object that might be blown over in a normal wind but would likely cause minimal damage and where the cost of prevention would be high. In such a case, the defendant might not be negligent under American law. ${ }^{45}$ Jewish law would, however, impose liability because the object could not withstand a normal wind. Although the distinction between normal and unusual winds involves the notion of foreseeability, ${ }^{46}$ at common law, foreseeability is but one element of showing that a defendant acted negligently. ${ }^{47}$ The plaintiff must further show that the defendant lacked reasonable care in preventing the foreseeable harm. ${ }^{48}$ For example, when the customer service department advised a customer to go up on her roof to repair a satellite dish, it was foreseeable that she might fall and be hurt. However, the company was not liable as a matter of law when she fell and

${ }^{44}$ Bava Kamma 55b; Maimonides, Hilkhot Nizkei Mammon 7:1.

${ }^{45}$ Cf. Andrews v. United Airlines, 24 F.3d 39 (9th Cir. 1994). The court allowed a jury to decide whether an airline used reasonable care when a briefcase fell from an overhead bin injuring a passenger. The court said, "Given the heightened duty of a common carrier ... even a small risk of serious injury to passengers may form the basis of liability if that risk could be eliminated "consistent with the character and mode of [airline travel] and the practical operation of [that] business . . .." Id. at 41.

${ }^{46}$ See Rashi, Bava Kamma 56a s.v. B'ruach she'einah metzuyah.

${ }^{47}$ Dan B. Dobbs, Paul T. Hayden \& Ellen M. Bublick, Hornbook on Torts 264-65 (2d ed. 2016).

${ }^{48}$ Id. at 265. As Lord Porter said in Bolton v. Stone [1951] AC 850 (HL) 858 (appeal taken from Eng.), "It is not enough that the event should be such as can be reasonably be foreseen. The further result that injury is likely to follow must also be such as a reasonable man would contemplate before he can be convicted of actionable negligence." 
was injured because the court said that the defendant's conduct did not unreasonably endanger her. ${ }^{49}$

Some Talmudic discussions seem to take into account more than the chance of injury. Consider the case where a person covers a pit in a public way in such a way that it will be safe for passing oxen but unsafe for passing camels who are presumed to be heavier. If camels occasionally, but not usually, pass over that spot and weaken the covering so that an ox later falls in, the one who covered the pit is liable because he ought to have had this possibility in mind. ${ }^{50}$ However, if camels are not found in that area but one happened to come by and cause the covering to weaken, the one who covered the pit would be exempt. ${ }^{51}$ Assuming that a stronger covering would be more expensive, these rules embody the idea that greater precaution needs to be taken when there is a greater chance that something will go wrong. However, the rulings do not require a case-by-case balancing of costs and benefits or a determination of reasonableness.

In his Guide for the Perplexed, Maimonides (1135-1204) sought to provide reasons for the Torah's laws. ${ }^{52}$ In one section, he explained three different rules about damage done by animals. ${ }^{53} \mathrm{He}$ wrote:

No compensation is enforced for damage caused by the mouth or the foot of an animal in a public thoroughfare; because this cannot be guarded against, and the damage caused there is not very large. ${ }^{54}$ Those who place their

${ }^{49}$ Lowery v. Echostar Satellite Corp., 160 P.3d 959, 965 (Okla. 2007). See also Stinnett v. Buchele, 598 S.W.2d 469, 471 (Ky. Ct. App. 1980) (holding that an employer was not negligent as a matter of law for asking an employee to paint a roof even though such work is dangerous).

${ }^{50}$ Bava Kamma 52a. The Rosh, Asher ben Jehiel (c. 1250-1327), interprets the text to mean that even if camels do not commonly pass there, if a camel fell in the pit, the one who covered the pit would be liable. Rosh, Bava Kamma 5:12. The Tur followed this approach, HM 410:9, as did the Rema in his gloss to Shulhan Arukh, Hoshen Mishpat 410:23.

${ }^{51}$ Bava Kamma 52a; Shulhan Arukh, Hoshen Mishpat 410:23.

52 Moses Maimonides, Guide for the Perplexed 3:30, ch. 30, 329-31 (M. Friedländer trans., E.P. Dutton \& Co., 2d ed. 1910).

${ }^{53} \mathrm{Id}$. at 342.

${ }^{54}$ Such damages are likely to be frequent and small. Friedländer's translation is preferred over that by Shlomo Pines that says that damage of tooth or foot is "seldom caused." Moses Maimonides, The Guide OF THE PerpleXed 555 (Shlomo Pines trans., University of Chicago Press 1963). Cf. Moses Maimonides, MoreH HA- 
things in a public place are themselves guilty of neglect, and expose their property to injury. But compensation is given for damage caused to the property of a person in his own field by the tooth or the foot of an animal. It is different in the case of damage caused by the horn of animals or the like. The animal can be guarded everywhere [and prevented from causing injury], whilst those who pass public thoroughfares cannot sufficiently take care against accidents of this kind..$^{55}$

As for the first rule - where Maimonides said an animal owner "cannot" prevent his animal from trampling objects or eating food in the public way-it seems that he meant that it would be prohibitively expensive to do so. ${ }^{56}$ So read, the first rule combines notions of cost/benefit, plaintiff's fault, and cheapest cost avoider. ${ }^{57}$

However, Maimonides did not establish a general rule that liability should be determined by a comparison of the costs of prevention and the expected damage. Maimonides offers no explanation for the rule imposing liability on an animal's owner for damage done in another's field done by the animal's tooth or foot. Presumably, it would still be prohibitively expensive for the animal's owner to prevent this type of damage once the animal had strayed onto another's land. However, the Torah imposed liability in this situation, ${ }^{58}$ and it may be that Maimonides thought that the landowner is entitled to have his goods protected on his own land even if he were the cheapest cost avoider. American law also recognizes that landowners have this right. ${ }^{59}$

As for damage caused by horn, when Maimonides said, "the animal can be guarded everywhere," he may have implied that the

NevuKhim 566 (Samuel Ibn Tibbon Hebrew trans. 2000) (the effect of such damage is small).

${ }^{55}$ MAIMONIDES, supra note 55, at 347.

${ }^{56}$ Similarly, the Rosh explained that it would be "impossible" for the animal's owner to constantly watch out for his or her animal so as to prevent damage by tooth or foot in the public way. Rosh, Bava Kamma 1:1.

${ }^{57}$ See Sinai \& Shmueli, Preliminary Sketch, supra note 4, at 87, 91-92, 104-06.

${ }^{58}$ Exodus 22:4.

${ }^{59}$ See, e.g., LeRoy Fibre Co. v. Chi., Milwaukee \& St. Paul Ry., 232 U.S. 340, 350 (1914) (holding a railroad liable for its negligence when a fire from its engine destroyed flax that plaintiff stacked on its land near the railroad; even though the damage could have been avoided had the plaintiff stored its flax further away, the plaintiff was not negligent as a matter of law for not anticipating the railroad's misconduct). 
owner can do this relatively inexpensively. However, Maimonides seems to emphasize that the animal owner is better able than the victim to prevent this kind of damage. In other words, the animal owner is the cheapest cost avoider in case of horn but not in the case of tooth or foot in the public way.

The Rosh also imposed liability on the cheapest cost avoider in a case involving rainwater that overflowed from one person's well into another person's basement. ${ }^{60} \mathrm{He}$ reasoned that it would be easier for the well owner to prevent the injury than it would be for the homeowner to protect his property. ${ }^{61}$

In Jewish law, some harms are deemed to be so unlikely to happen that there is no liability. For example, a fire cannot be expected to cross a body of water that is at least eight cubits wide. ${ }^{62}$ If harm nonetheless results, Maimonides says this is a blow from Heaven. ${ }^{63}$ The defendant is exempt without regard to either the amount of expected harm or the cost of prevention. Similarly, the Talmud concludes that one who covers a pit with a plank of wood need not knock the wood to see if it has remained strong. ${ }^{64}$ Although the defendant could have prevented injury with minimal expense and even though the expected damage to cattle crossing over the covered pit can be estimated, the Talmud imposes no liability based solely on the low chance of having rotten wood. Perhaps the Talmud has in mind a temporary covering for a pit where the risk of termite damage to new boards in the near future is extremely low. However, Maimonides makes a similar ruling when a rung of a ladder comes loose and a person climbing the ladder falls and causes injury to one below. ${ }^{65}$ Maimonides exempts one from tort liability if the rung was firmly in place but rotten inside. ${ }^{66}$ Again, Maimonides calls this a blow from Heaven. ${ }^{67}$ Yet the burden of occasionally checking a ladder for termite damage is extremely low, and the expected damage might be high.

${ }^{60}$ Responsa Rosh 108:10.

${ }^{61}$ Id.; see also Yaakov Lorberbaum (C. 1770-1832), Netivot HaMishpat, Bi'urim 155:3 (stating that a defendant must remove the source of damage when the plaintiff's costs of preventing the damage are high).

${ }_{62}^{62}$ Maimonides, Hilkhot Nizkei Mammon 14:2.

${ }^{63} \mathrm{Id}$.

${ }^{64}$ Bava Kamma 52b.

${ }^{65}$ Maimonides, Hilkhot Hovel U-mazik 6:4.

${ }^{66} \mathrm{Id}$.

${ }^{67} \mathrm{Id}$. 
If negligence is not the basis for the rules of liability laid down by the Talmud and later rabbinic sources, what is? It seems that some of these rules are based on the customary conduct of the time. For example, the Jerusalem Talmud explains the rule that one who runs in a public way is liable for injuring someone who is not running by saying that the defendant "changed the custom." ${ }^{68}$ By contrast, if the injury occurred on a Friday afternoon shortly before the beginning of Shabbat, the runner is exempt. ${ }^{69}$ The reason apparently is that people are often in a hurry before the onset of Shabbat. ${ }^{70}$ Similarly, the Tosefta reports that if a worker or poor person who was climbing a tree fell and broke a sukkah, he would be exempt if he acted in the place where such conduct regularly occurs. ${ }^{71}$ Other rules, as we have seen, ${ }^{72}$ reflect a sense of imposing the loss on the cheapest cost avoider.

If the classical sources of Jewish law do not employ the negligence doctrine, why have scholars said otherwise? One reason might be that scholars have wanted to understand and explain Jewish law in terms that are familiar to them and their audience. It also may have resulted from a desire to have Jewish law play a role in the development of the law of a (future) Jewish state. If Jewish law were to lack the concept of negligence so fundamental to Western culture, one might think that Jewish law would have little to teach us about law in general.

The effort to read Western notions of liability into Jewish law can distort our understanding of the original sources. We can see this happen in the law governing medical malpractice. The Shulhan Arukh ruled as follows:

The Torah gave the doctor permission to heal, and it is a commandment that is included in the obligation to save life. If he prevents himself [from healing] then he sheds blood.... However, a person should not practice

\footnotetext{
${ }^{68}$ Jerusalem Talmud, Bava Kamma 3:7. The bailee's breach has sometimes been referred to as "negligence." See Isidore Epstein, Babylonian Talmud, Bava Metzia 252 (1935); David Daube, Negligence in the early Talmudic Law of Contract (Peshi'ah), in 1 Collected Works OF David Daube 305 (Calum M. Carmichael ed., 1992). However, the bailees' standard of care is established by custom. See Mishnah, Bava Metzia 3:10; Bava Metzia 93a-b.

${ }^{69}$ Jerusalem Talmud, Bava Kamma 3:7.

${ }^{70}$ See Bava Kamma 32a-b.

${ }^{71}$ Tosefta, Bava Kamma 10. C.f. Jerusalem Talmud, Bava Kamma 10:4 (saying that the defendants are exempt if they acted at the regular time for such activities).

${ }^{72}$ See supra notes $57-60$.
} 
medicine unless he is an expert and unless there is none present who is greater than him, for otherwise he sheds blood. If he treated without the permission of the court, he is liable to make compensation even if he is an expert. If he treated with permission of the court and erred (ta ${ }^{\prime}$ ah) and caused injury, he is exempt under the laws of man but liable under the laws of Heaven, and if he killed [the patient] and it is known to him that he was inadvertent (she-shagag), he goes into exile on his account. ${ }^{73}$

The Shulhan Arukh exempts doctors from liability under the laws of man for errors as long as they are experts and have permission of the court. ${ }^{74}$ This is an exception to liability normally imposed when one causes personal injury. ${ }^{75}$ It results from an early ordinance that is reflected in four different sections of the Tosefta. ${ }^{76}$ Of course by modern standards, almost all medieval medical practice was in error. Presumably, by "error," the Shulhan Arukh means failure to comply with accepted medical practices of the time.

So understood, the Shulhan Arukh establishes a standard of care similar to that common in American law in that the standard of medical practice is what doctors customarily do. Although the standards look similar, the legal consequences are not. Under Jewish law, doctors who fall short of the professional standard are exempt under the laws of man and liable under Heavenly law. By contrast, American law would hold such a doctor liable.

The matter is complicated, however, because one part of the Tosefta says, "If an expert physician having permission of the court to heal injured, he is exempt, but if he did more harm than was appropriate he would be liable."77 The Shulhan Arukh did not codify the latter part of this provision, and it might perhaps be dismissed as a minority view. However, the Tashbatz, Rabbi Shimon ben Tzemach Duran

${ }^{73}$ Shulhan Arukh, Yoreh De'ah 336:1.

${ }^{74}$ During the Middle Ages, each semi-autonomous local Jewish community, known as a kahal, had the status in Jewish law of being a court. A physician hired by the kahal for the benefit of its members was therefore regarded as having "permission of the court." See Steven F. Friedell, Medical Malpractice in Jewish Law: Some Parallels to External Norms and Practices, 6 CHI-Kent J. INT'L \& COMP. L. 1, 11 (2006).

${ }^{75}$ See supra notes $15-16$.

${ }^{76}$ Tosefta, Bava Kamma 6:17, 9:11; Gitin 3:6; Makkot 2:5.

${ }^{77}$ Tosefta, Bava Kamma 9:11 (S. Lieberman ed.). 
(1361-1444), said that this section of the Tosefta referred to harm done by surgeons. He stated his conclusions as follows:

A rofe uman who has permission of a rabbinical court to treat who errs and injures [a patient], and other surgeons recognized his error, is liable whether by inadvertence or intention under the laws governing a tortfeasor. If he killed [the patient] he is under the law governing murder. If he did not err but did what was appropriate but caused physical injury through his wrongful inadvertence, he is exempt for the sake of social order [mipnei tikkun ha'olam] and his case is referred to Heaven [for judgment]. If he killed [the patient], he goes into exile. If he did more than was appropriate, then he is a tortfeasor or murderer [as the case may be] and [either] pays [damages] or is put to death if he was warned [by witnesses beforehand]. If he was not warned, he may be killed by the blood redeemer ...

It appears that the meaning of rofe uman is a one who treats injuries by work of the hand, whose inadvertence and intentional [acts] are torts or murders through the use of an iron [tool], because the Torah has provided that even if a small needle [kills a person, the court is not] required to estimate whether it was capable of doing so ... Also, the word uman means a person who cuts with an iron [tool]...

However, a physician [who treats] the sick by liquids, laxatives, drugs, baths, and rest is not called a rofe uman but simply a rofe. He is not governed by the above rules [applied to surgeons] for he will not enter into the realm of wounding (she-eino ba li'yidei chavala) as to be liable in tort. If he acted inadvertently or with intention and killed [a patient] or added to the illness's pain, then as long as he intended to heal and not to injure, he is exempt even under the laws of Heaven, for he only has what his eyes can see. 
However, he must not speak in front of one who is wiser than him, as is the case with judges. Nor shall he rely on his own experiments. Of them it is said, "the best of physicians are destined for Gehenna. ..." ."78

Although at least one authority relied on the Tashbatz's ruling ${ }^{79}$ the later codes have not endorsed it.

Some have maintained that the Tashbatz's ruling was based on the law of indirect damages (garmi and gerama). ${ }^{80}$ That is, the surgeon injures a patient directly, a case of garmi, and is therefore liable, whereas the physician injures only indirectly, a matter of gerama and is therefore not liable. This explanation is difficult, however, because according to several authorities, in case of gerama, one is liable under the law of Heaven rather than entirely exempt. ${ }^{81}$ However, the Tashbatz ruled in another case that, to be a case of gerama, the defendant must have performed some act, ${ }^{82}$ and it is possible that he considered physicians, as long as they restricted themselves to giving advice, as not performing an act.

It seems more likely that the Tashbatz reasoned that a physician (other than an empiric, one who relied on his own experiments) is not a tortfeasor (an adam ha-mazik) as long as he intended to act for the patient's benefit. ${ }^{83}$ If so, the exemption pertained to qualified physicians even if they applied a treatment directly to their patients' bodies.

\footnotetext{
${ }^{78}$ Shimon ben Tzemach Duran, Responsa Tashbatz 3:82.

${ }^{79}$ Isaac Molina, Responsa Besamim Rosh 386 (1793).

80 See J. David Bleich, Medical Malpractice and Jewish Law, 39 Tradition 69, 96 (2005).

${ }^{81}$ See, e.g., Solomon Luria, Yam shel Shlomo, Bava Kamma 9:18; see also Isaac Jacob Weiss, Responsa Minchat Yitzchak 3:104 (discussing the difficulty underlying the Tashbatz's ruling concerning physicians); Bleich, supra note 80, at 100.

${ }^{82}$ Shimon ben Tzemach Duran, Responsa Tashbatz 2:114.

${ }^{83}$ See Shita Mekubetzet, Bava Kama 27a s.v. ve-khen katav (view of the Riva); Joseph Dov Soloveitchik, Reshimot Shiurim Bava Kamma 188 (1999) (comment to Bava Kama 27a); 14 Piskei Din Yerushalayim Dinei Mammonot U-beirurei Yuchsin 338, 339 (2015); see also Bleich, supra note 80, at 99 (coming to a similar conclusion based on the view expressed by the Me'iri that one is not liable for indirect injury unless one intends to do harm).
} 
The Tashbatz's disapproval of empirics requires a different explanation. ${ }^{84}$ These physicians had no theory of disease, ${ }^{85}$ and it is likely that the Tashbatz did not consider them to be qualified to practice medicine. Qualified physicians of his time were trained according to the classical theories of disease and treatment. ${ }^{86}$

As late as the end of the nineteenth century, rabbis maintained that a doctor was not liable for errors except in a court of Heaven. ${ }^{87}$ Rabbi Yechiel Epstein in his Arukh HaShulhan introduces the concept of negligence (hitrashlut) into the discussion by saying that a doctor is only liable for negligence in a court of Heaven. ${ }^{88}$

Contemporary rabbis and scholars have transformed the law of medical malpractice. ${ }^{89}$ One scholar, Michael Wygoda, head of the Jewish law department at Israel's justice ministry, summarized current rabbinic views by saying that the Shulhan Arukh only addressed a doctor who is not negligent. ${ }^{90} \mathrm{He}$ explained that others have applied the Tashbatz's ruling imposing liability for doing more than appropriate to all doctors, including physicians. ${ }^{91}$ And he said that doing more than what is appropriate included acting with lack of caution ( $z^{\prime}$ hirut $){ }^{92}$

One of the rabbis relied on by Dr. Wygoda ruled that a dentist who inadvertently and negligently ("she-hitrashel") drilled on the wrong tooth would be liable as an intentional wrongdoer and was therefore liable for full damages beyond that of nezek..$^{93}$ Similarly, Shlomo Dichovski, a distinguished rabbi and member of Israel's Supreme Rabbinical Court wrote, "If a doctor did his job negligently ("she-hitrashel"), did not perform appropriate tests or neglected his

\footnotetext{
${ }^{84}$ Rabbi Bleich does not mention the Tashbatz's discussion of empirics. See Bleich, supra note 80, at 99 (describing the Tashbatz's distinction between surgeons and physicians).

${ }^{85}$ Roswell Park, An Epitome of the History of Medicine 14-15 (1897).

${ }^{86}$ Ron BARKaI, A History of Jewish GyneCological TeXts in the Middle Ages 38 (1998); I.E. Drabkin, Soranus and his System of Medicine, 25 BULL. HIST. MED. 503, 504-05 (1951).

${ }^{87}$ See Yechiel Michel Epstein, Arukh HaShulhan, Yoreh De'ah 336:2.

${ }^{88} \mathrm{Id}$.

${ }^{89}$ See generally Steven F. Friedell, The Recent Transformation of Medical Liability in Jewish Law, 14 DePaul J. Health Care L. 441, 445 (2013).

${ }^{90}$ Michael Wygoda, Ve-Rapo Y'rapeh, Parashat Ha-shavu'a No. 415 at 2, Ministry of Justice, Jewish Law Section (2012/13).

${ }^{91} \mathrm{Id}$. at 3.

${ }^{92} \mathrm{Id}$.

${ }^{93}$ Shmuel Halevi Wosner, Responsa Shevet Halevi 4:151 (1981).
} 
patient, he is liable in a human court."94 Rabbi Halevi, former Sephardi chief rabbi of Tel Aviv, wrote that a physician who made an error in diagnosis or treatment would be liable if the error was not "reasonable." $" 95$

It seems therefore that Jewish law has absorbed the doctrine of negligence, including the concept of reasonableness. It did so largely by adopting the values of the surrounding culture. ${ }^{96}$

Although some may see this as progress, it comes at a price. We have lost the sense that the Talmud's rules of liability were not based on the standard of reasonable care or on a cost/benefit calculation but were a collection of rules of conduct. ${ }^{97}$ Some of these rules were based on custom ${ }^{98}$ or a sense of the cheapest cost avoider. ${ }^{99}$ Other Talmudic rules limited the range of damages that were owed. ${ }^{100}$ On a more particular level, we have lost sight that the Tashbatz thought that physicians, other than empirics, should be exempt even under the laws of Heaven even if they caused injury through intentional acts, and that surgeons should be liable for damage if they cut the patient more than needed. ${ }^{101}$

On further examination, however, it appears that the Tashbatz was himself influenced by his surrounding culture where surgeons

94 Shlomo Dichovski, Miteshuvotav shel rav l'rofe, 17 TECHUMIN 327, 332 (1996/97), quoted in CivA 9656/03 Marciano v. Singer \ 24, Nevo Legal Database (by subscription, in Hebrew) (April 11, 2005) (Isr.) (Rubinstein, J.).

953 Hayyyim David Halevi, Aseh Lekha Rav, Responsum no. 30, 138, 144 (1978/79).

${ }^{96}$ For another example of this phenomenon, see Ron Kleinman, The Halakhic Validity of Israel's Judicial System among Israeli Ultra-Orthodox Halakhic Decisors, 18 REV. RABBINIC JUDAISM 227, 249 (2015) (reporting that Rabbi Asher Weiss called for rabbinical courts to permit plaintiffs to bring suit in civil court in situations where plaintiffs would receive no compensation in rabbinical court but could be awarded substantial damages in civil court). See also Aharon Lichtenstein, Shi'urei Harav Aharon Lichtenstein, Dinei D'garmei 200 (1999/2000) (contending that rabbinic authorities ought to prevent harm to the public by allowing tort victims to be compensated even though their injuries were indirectly caused).

97 See supra notes 30-34 and accompanying text.

${ }^{98}$ See supra notes 68-71 and accompanying text.

${ }^{99}$ Responsa Rosh, supra note 60.

${ }^{100}$ See supra notes 13-16 and accompanying text.

${ }^{101}$ Shimon ben Tzemach Duran, supra note 78. 
were of a lower class, less skilled and less trained than physicians, ${ }^{102}$ and where empirics were what we could call quacks. ${ }^{103}$

Could it be that such borrowing and assimilation of external values has always been part of the history of Jewish law?

102 See Michael R. McVaugh, Medicine Before the Plague: Practitioners AND THEIR PATIENTS IN THE CROWN OF ARAGON, 1285-1345 183 (1993); Byron Grigsby, The Social Position of the Surgeon in London, 1350-1450, 13 ESSAYS Medieval Stud. 71 (1996).

103 See PARK, supra note 85. 